\title{
Features of protection of the rights of the buyer of residential premises with the participation of a minor in the transaction
}

\author{
Marina Ulianova* and Lidia Zarapina \\ Department of Civil Law, Russian State University of Justice, Moscow, Russia
}

\begin{abstract}
Changes in social and economic relations in society have affected the rights of certain categories of citizens-minors, the protection of whose rights is a priority. In transactions with residential premises, the protection of the rights of minors is also a priority. However, this approach has created a situation where the weak side in real estate transactions is another entity - the buyer, whose position has become vulnerable. As a result of the conducted research, individual situations in which there is a violation of the rights of the child are identified. The rights of the child are exercised by his legal representatives, and therefore a transaction made in violation of the law is recognized as contrary to the foundations of order and morality. This entails the recognition of the transaction as invalid and the consequences in the form of bilateral restitution, which violates the right and legitimate interests of the buyer in a real estate transaction. If the legal representative has no funds or their insufficiency by the time the transaction is declared invalid, the court decision regarding the full refund of funds will remain unfulfilled, and the buyer's rights are violated.
\end{abstract}

\section{Introduction}

Changing social and economic conditions have generated a lot of "unverifiable risks" [1,2], in which the turnover of residential premises is carried out. It is methodologically necessary to highlight some stages of the development of ideas about the rights to residential premises, which will allow us to understand in detail the origins of the problem. So conditionally, the first stage is defined as the Soviet period of state development. In the Soviet period, relations on the use of residential premises based on an order for the provision of residential premises were common and did not imply the possibility of a wide turnover of residential premises. For example, when receiving residential premises by inheritance, the owner did not have the right to use the residential premises for profit, for example, for renting (Article 10 of the Housing Code of the RSFSR), private property, although the legislator, but its volume provided for it was very small.

The next stage (the second) is connected with the development of commercial relations in society and the need to solve the housing problem. Changes in the economy in property relations have led to a change in the attitude to residential premises as an object of property rights. The desire to solve the housing problem in society by involving housing in civil circulation has given rise to an attitude towards residential premises as ordinary civil objects.

In a society where there was no "owner's psychology", as the result of privatization, millions of Russian citizens were "given the right to own residential premises" overnight. For that period, the application of paragraph 2 of Article 209 of the Civil Code of the Russian Federation was characteristic in terms of "the owner has the right to perform any actions in relation to the property belonging to him at his discretion". In isolation from the continuation of this norm, which fixed the following rule that these "any actions" should be "not contrary to the law and other legal acts and not violating the rights and legally protected interests of other persons".

Such an approach gave rise to a bias towards protecting the rights of the owner, including his right to dispose of property. Thereby entailing a number of violations of the housing rights of unprotected segments of the population at that time, which included children, disabled family members, persons in military service or persons serving sentences in places of deprivation of liberty, at the time of concluding a transaction for the purchase and sale of residential premises. The rights of these persons were violated if they were family members of the owner or users of the residential premises who refused to privatize the residential premises in relation to themselves, retaining the right to use the residential premises indefinitely. Thus, it should be noted the dual nature of the residential premises, both the object of property rights and the object of housing rights.

Doctrinal studies of the nature of residential premises as an object of civil law and housing rights, increasing judicial practice regarding violations of the rights and interests of other persons, allowed us to talk about limiting the "priority" of the owner's rights and taking into account the rights and interests of persons who have the right to use residential premises.

* Corresponding author: maryulianova14@gmail.com 
The third stage defined as the stage of state support and related new types of disputes. At the same time, it should be noted that at the second and third stages, the priority issue was the protection of the rights and legitimate interests of the child in housing relations. The Russian Federation has ratified the Convention on the Rights of the Child, which has become part of its legal system. In the late 1990s and early 2000s, the works of Yu enriched the Russian doctrine. F. Bespalov and other authors devoted to the understanding of the legal status of the child, as well as the definition and protection, including the housing rights of the child, as an independent subject. It was during this period that the position of the child in the doctrine understood not only as an independent subject of civil legal relations, but also as a person in need of special care, both from parents and from the state.

This position became even more relevant in the 2010s, in the light of the perception of relations on the use of residential premises as socially oriented in society. The basis of social orientation in the perception of residential premises was the Concept of the Development of Civil Legislation of the Russian Federation (hereinafter-the Concept) (paragraphs 7.3 and 3.8). So, with the transition to "personal property and market relations" in the 90s of the XX century, residential premises considered as an object of civil turnover, which is what attention is paid to in the Concept.

Further, implementing the Concept, the legislator is not only recognized as residential premises, which are technically separate parts of residential buildings (paragraph 1p. 1st. 130 of the Civil Code of the Russian Federation and paragraph 2 of Article 15 of the Housing Code of the Russian Federation). The ownership right to that arises from the moment of state registration; it also indicated the social significance of the residential premises in relation to the rights of persons who have the right to use it. Thus, a residential building, which is an object of civil and housing rights, has a socially significant function to meet an important human need [3].

Within the framework of scientific works, the need to protect the rights of minors in all its aspects, including in the sphere of participation of minors in civil turnover and in transactions with residential premises, has been discussed and is still relevant today [4]. However, the issue has become acute and it is necessary to pay attention to the other side of this problem - to protect the rights of the buyer of residential premises. It is the buyer who becomes the weak party in the obligation if on the seller's side one of the right holders is a child who is the owner or co-owner of residential premises. One's share in the ownership is alienated (for example, he is a coowner of his parent or other relative), or has the right to use the residential premises. Thus, we can distinguish the following position of the child in the relations under consideration: 1) the child is the owner, co-owner of the residential premises; 2) the child has the right to use the residential premises as a member of the owner's family.

The modern period characterized by the fact that a child acquires the right of ownership because of a civil transaction, inheritance, but also because of the use of state support measures by his parents, legal representatives. Thus, we can distinguish the following: 3 ) the child is the subject of a relationship in which his family has taken advantage of state support measures aimed at improving the family's living conditions, because of which the parents have pledged to allocate him a share by virtue of the law.

Thus, in accordance with Article 7 of the Constitution of the Russian Federation, the Russian Federation is a social state. As part of the measures of state support for families aimed at improving housing conditions and increasing the birth rate, the Federal Law "On Additional Measures of State Support for Families with Children" (hereinafter - FZ-256) was adopted in 2006. In addition to this document, there are programs to provide citizens with housing.

Within the framework of these programs, a child, taking into account which funds were provided or in connection with whose birth the right to a measure of state support arose, is also entitled to a share in the ownership of a residential building that was purchased (built) with the involvement of state family support funds. However, the time of purchase of housing, the allocation of the corresponding share and the indication of the child in the real estate register as the owner do not coincide. The issue of the size of the allocated share and the possibility of allocating a share in an object of unfinished construction is ambiguously resolved, which requires detailed theoretical study.

\section{Results}

As a result of the study of legislation and law enforcement practice, it was revealed that a not unimportant point for concern and the development of ways to protect the rights of the buyer of residential premises is that state support measures are targeted, and therefore relate to the sphere of public relations. And their implementation is under the control of the state. However, the norms do not have a detailed specification and the completion made by the interpretation of the highest judicial body.

One of the ways of protection, as a measure aimed at restoring the violated rights of the child, is the recognition of the transaction as invalid. Thus, the rights of a child are exercised and protected by his legal representatives-parents (Article 56.57 of the Family Code of the Russian Federation). Therefore, a transaction made in violation of the law is recognized contrary to the basics of order and morality [5]. This entails the recognition of the transaction as invalid (void) and the application of the consequences in the form of bilateral restitution, which violates the rights and legitimate interests of the buyer in a real estate transaction. However, if the legal representative has no funds or their insufficiency by the time the transaction declared invalid, the court decision regarding the full refund of funds will remain unfulfilled, the child's right restored, and the buyer's rights violated. 
Taking into account this approach, attention should be paid to the protection of the rights of both minors and persons acquiring residential premises from a minor or when acquiring a share in the property right, where the minor was a co-owner or other right holder. Similar precedents have taken place. Thus, a case considered on the claim of guardianship and guardianship in the interests of a minor for the recognition of the transaction as invalid and the application of the consequences of the invalidity of an insignificant transaction. It followed from the circumstances of the case that, with the proper consent of the guardianship and guardianship authorities, the child's mother did not purchase another room for the child, but moved to another region and spent the funds received for her and the child's household needs, having no other income and not working.

In this situation, the court, when making a decision, took measures and protected the rights of the parties by applying the institution of bilateral restitution. If the transaction is invalid, each of the parties is obliged to return to the other everything received under the transaction. However, it clearly followed from the case materials that the seller is unlikely to return the money. In another case, the pope disposed of his share in a residential building by donating it to several outsiders. For the children and the ex-wife, this was the only accommodation for living. As a result, the court also qualified the transaction as contrary to the principles of law and order and morality, and applied restitution because of invalidity.

In another case under consideration, the mother was disposed of the residential premises, while the child who has the right to use the residential premises was in a State boarding institution. The transaction declared invalid in the interests of the child. The buyer of residential premises can use borrowed funds to purchase it, as well as have dependent minor children, and in such a situation, protection of the rights of not only the child on the seller's side, but also the buyer is required.

However, there may be situations when parents used targeted funds when purchasing residential premises, which provided based on all family members, including children. One example of such a situation is the following. Citizens did not allocate a share to children, or they did, but in violation of the explanations of the data of the Armed Forces of the Russian Federation, which appeared more than 10 years after the beginning of the law. So, the legislator, and beyond him, and in some cases, law enforcement officers do not indicate to what extent, on what principle it is necessary to allocate a share to children in the ownership right to all residential premises, to part of the residential premises and to this obligation.

The spouses in all the analyzed judicial acts mistakenly believed that the funds of the maternity capital are jointly acquired property and the maternity capital is subject to equal division between them, which is not true. When making a decision, the disputed property should be subject to division, taking into account the requirements of Articles 38, 39 of the IC of the Russian Federation and Part 4 of Article 10 Federal Law No. 256-FZ of 29.12.2006 "On additional measures of state support for families with children". This means the allocation of shares for minor children, and taking into account the principle of proportionality of the invested funds of the maternity capital.

Therefore, a difficult situation is that when parents allocated a negligible share to their children, which does not correspond to the proportionately provided funds of the maternity capital, and later sold the residential premises.

The next element of the legal relationship in relation to which there is no unambiguous indication in the law is the object. Thus, the legal literature has repeatedly raised questions about the allocation of children in the objects of unfinished construction. Yu raises this question in his work. Shuttles, denoting the specified problem [6]. It should be noted that the legislator provided in subparagraph 1 of paragraph 1 of Article 10 of the Federal Law-256 the possibility of directing the funds of the maternal (family) capital for the purchase of a residential house under construction, which gave rise to a certain category of disputes.

The supreme judicial body of the Russian Federation has brought some clarity to this situation, the definition states that "the Federal Law specifically regulating the relevant relations is the Federal Law defining the circle of subjects whose property receives residential premises purchased using maternity capital, and the type of property is established-common equity, arising from them on the purchased housing. The funds of the maternal (family) capital have a special purpose. And therefore, based on the provisions of these legal norms (FZ-256 and the IC of the Russian Federation), children should be recognized as participants in shared ownership of a real estate object acquired (built, reconstructed) using maternity capital funds". Thus, the law enforcement officer protected not only the rights of the child, but also prevented violations of the rights of a potential buyer of such a real estate object.

Another author, S. V. Chashkova, draws attention to the controversial issues of the moment of the emergence of the ownership right to residential premises acquired using the funds of the maternal (family) capital $[7,8]$. Thus, in a departure from the generally accepted moment of the emergence of the right of ownership, in order to bring "clarity", the author suggests that the moment of the emergence of the right of ownership is "the moment of receipt of the funds of the maternity capital at the disposal of their recipient". We believe that this approach is quite justified. Although it does not combine with the canons of civil law, and requires the development of legislation in terms of protecting the rights of persons, possible buyers of residential premises, if the parents do not fulfil their duty and do not formalize the transfer of ownership rights in relation to the child's share.

In these relations, the buyer can protect himself by asking for documents confirming the use of state support measures and the proper fulfilment of their obligations by the parents, or to prove a negative fact, which in itself is unlikely.

There are situations when subsequent children were born after the transfer of funds from the maternity 
capital, but before the registration of ownership of the residential premises. Do subsequent children have ownership rights? Courts and notaries usually answer yes. We believe that the solution of this issue is in the sphere of solving the issue of the circle of persons, taking into account, which funds provided for the purchase of residential premises. Therefore, if the support funds provided and used to improve the housing rights of a family in a certain composition, then the right of ownership can arise only from these persons.

When using the funds of the family (maternal) capital, you should also pay attention to the composition of the family when using the funds, and in respect of whom law makes the obligation. It would seem that this violates the principle of justice, but in connection with the birth of subsequent children, the family may have other grounds for improving housing conditions in connection with his birth. Thus, by virtue of Article 72 of the Constitution of the Russian Federation and paragraph 1 of Article 5 of the Housing Code of the Russian Federation (hereinafter - the Housing Code of the Russian Federation), housing legislation is the subject of joint jurisdiction of the Russian Federation and its subjects and by virtue of Article 49 Housing and communal services of the Russian Federation. The subjects of the Russian Federation may provide additional grounds for providing residential premises. Thus, in a number of regions, it is provided for the provision of maternity capital funds at the birth of the third and subsequent children. Therefore, it is important to determine the subject composition of the relationship, at the time of the parents ' obligation to transfer the share in the ownership of the residential premises to the children.

The works of E. Serebryakov [9], E. Natyrov [10] and other authors' wrought in detail about the use of family (maternal) capital, including for the purchase of housing, but the topic is not completely exhausted. When using these funds, various violations arise, which inevitably leads to a court, where the judge will already determine the legality of using the funds and the absence of violations of the rights of minors in connection with their use. However, by the time the disputes are considered, the residential premises may already be sold and the buyer is not aware of the violation of the rights of the child at the time of the transaction.

The buyer of the residential premises, in turn, has information about the real estate object that specified in the unified real estate register, and provided by the owner of the residential premises. Whether the funds of the maternity capital were used, whether a share was allocated to children in proportion to the funds provided, whether the rights of the child were somehow violated when selling residential premises? These are questions that the buyer does not have an answer to when concluding a transaction. And one cannot get information if the seller hides it or is mistaken about the situation himself. However, the risk of recognizing the transaction as contrary to the principles of law and order and morality (Article 168 of the Civil Code of the Russian Federation) still lies with the buyer due to the consequences provided for by law (Article 167 of the Civil Code of the Russian Federation).

In the case when the share allocates, a mechanism for protecting rights provides. The legislator provided for the necessary preliminary consent of the guardianship and guardianship authorities and notarization of the transaction for the sale of a share in the right of common ownership to an outsider.

I would also like to draw attention to the interrelated provisions of Article 8.1 of the Civil Code of the Russian Federation and the norms of 218-FZ. Thus, Article 8.1 of the Civil Code of the Russian Federation contains the fundamental rules of state registration of property rights, which are subject to application regardless of what is the object of registration. This rule applies to registration in various registers (paragraph 3 of the Resolution of the Plenum of the Supreme Court of the Russian Federation No. 25).

The persons who are not parties to the transaction and did not participate in the case, considered that as the rights to property subject to state registration. They change and terminate from the moment the corresponding entry is made in the state register, and not at the time of the transaction or the actual execution of the transaction or the entry into legal force of a court decision. On its basis such rights arise, change or terminate (paragraph 2 of Article 8.1, paragraph 2 of Article 551 of the Civil Code of the Russian Federation). At the same time, from the moment when the relevant grounds for state registration of the right arise, the parties of such transaction or the persons participating in the case, as a result of consideration of which the said court decision was made, are not entitled to refer in bad faith to the absence of an entry about this right in the state register.

In the case the share of a minor is not allocated, the buyer does not have information about the use of family (maternal) capital, based on the rules on the invalidity of transactions. They are contrary to the principles of law and order and morality, as well as existing judicial practice; the buyer bears the risk of acquiring residential premises under the contract of sale.

E. Pozdnysheva draws attention to the moment of termination of such a contract, committed in violation of the norms of substantive law [11]. It turns out that if the contract of purchase and sale of residential premises concluded and registered accordingly, then if it declared invalid, a corresponding entry made in the unified state register on the termination of the contract and the termination of the rights to the disputed residential premises.

Another important circumstance in which a transaction declared invalid by virtue of Article 250 of the Civil Code of the Russian Federation is the refusal of the child's co-owner from the pre-emptive purchase of a share. Due to natural reasons, under the circumstances provided for by law, his legal representative exercises the rights of a minor in civil law transactions. Refusal to acquire a share in the ownership of residential premises may worsen the living conditions of a minor. In this connection, the legal representative of a minor may not receive approval to refuse a preferential purchase from 
the guardianship and guardianship authorities. At the same time, a minor, as well as his legal representative (parent, guardian, and trustee) may not have the material means to purchase housing. Even if the parent or legal representative has funds, the share acquired by a minor, which does not always correspond to the interests of the parent or legal representative himself. At the same time, when concluding a transaction in violation of paragraph 2 of art. 250 of the IC of the Russian Federation, in violation of the right of pre-emptive purchase, a participant in shared ownership may demand that the rights and obligations of the buyer be transferred to him within three months.

Such authors as Yu. Bespalov [12], A. Myskin [13], S. Nikolyukin [14] and others drew attention to certain aspects of the protection of housing rights and the rights of minor children as participants in transactions.

Legislative changes in recent years related to the protection of citizens ' rights in real estate transactions significantly expand the rights of the notary, introducing a monopoly on a number of transactions that can now be registered only with the participation of a notary. The contract of sale, exchange, and donation is subject to mandatory certification by a notary, if the apartment (even partially) belongs to an incapacitated/partially capable person, or a minor.

Initially, it planned that the introduction of the institution of mandatory notarization of transactions should protect the rights of persons who cannot do it on their own, and significantly increase the transparency of legal relations in the real estate market. However, the socalled human factor can play an important role, since the registration authorities no longer check the completeness and objectivity of the data subject to registration, operating only with information provided by a notary. Kochanova T. [15], Pryazhennikova K. [16] and others write about the features and risks of such in their works.

So K. Pryazhennikova gives an example when the guardianship and guardianship authority was given preliminary permission to conclude a contract for the purchase and sale of real estate belonging to a minor. Subsequently, the guardian (trustee) he released or removed from the relevant duties before the expiration of his term of office, while the act of appointing this person as a guardian (trustee) remained with him due to his bad faith. When this person applies to the notary office with a request to execute the relevant transaction, the former guardian (trustee) can present all the necessary documents, including the permission of the guardianship and guardianship authority for the transaction. This does not have a certain deadline, or the designated period is sufficient for the transaction, as well as an act of his appointment. The notary, certifying the transaction, verifies the powers of the guardian (trustee) in accordance with the Regulations based on the act on his appointment. If there is no other way to verify the existence of the authority of this person at the time of the transaction, the specified transaction will subsequently be declared invalid.

The lack of a full-fledged possibility of establishing the powers of a legal representative of a minor by a notary is one of the key problems of performing notarial actions with the participation of minor citizens.

The way out of this situation, in the case of representation of the rights and legitimate interests of a minor by a guardian (trustee), may be the provision by the guardian (trustee) of an appropriate document issued by the guardianship and guardianship authority. This confirms the validity of the powers of the legal representative at the time of his application for a notarial action, in which the ward is a participant.

Thus, the legislator is following the path of eliminating situations that contribute to the violation of rights. However, it seems that further measures should be provided for the protection of both the rights and legitimate interests of minors and the rights of the buyer in the situation of selling a share in the right of common ownership of residential premises where the co-owner is a child or the child is another right holder.

\section{Conclusion}

Because of the conducted research, some historical stages of the development of ideas about the rights to residential premises are highlighted. Residential premises are the object of civil rights, housing and state social support measures. As a result, we concluded that the current stage is characterized by the priority of legislative protection of the rights of minors in real estate transactions with a social orientation, which contributes in some cases to the violation of the rights of the buyer.

In our opinion, it is necessary to clearly distinguish civil, housing and state support relations. Filling in the missing detail of legal models, mechanisms of legal regulation of relations for the provision of state support measures for families we improve housing conditions. This would guarantee compliance with and protection of the rights and interests of the parties to the contract of sale of residential premises.

\section{References}

1. M. Ilyushina, Family and Housing Law, 3, 33-36 (2016)

2. B. Gongalo, P. Krasheninnikov, in the book: Codification of Russian Private Law (ed. D. Medvedev) (Statute, Moscow, 2008) p. 211

3. M. Ulianova, Justice, 3, 29-35 (2015)

4. L. Mikheeva, Real Estate. Construction. Law, 3, 107112 (2007)

5. E. Tuzhilova-Ordanskaya, V. Lukyanenko, Bulletin of Perm University, 45, 519-535 (2019)

6. Yu. Chelnokov, Law, 1, 91-109 (2021)

7. S. Chashkova, Notary Bulletin, 4, 40-55 (2021)

8. S. Chashkova, Laws of Russia: experience, analysis, practice, 5, 35-43 (2019)

9. E. Serebryakova, Editorial Office of Rossiyskaya Gazeta, 9, 176 (2019) 
10. E. Natyrova, Regulations for accountants, 7, 16-17 (2021)

11. E. Pozdnysheva, Cancellation of a civil contract: monograph (SISP, Moscow, 2018) p. 232

12. Yu. Bespalov, Housing disputes. Guide to legislation and judicial practice: a scientific and practical guide (Prospekt, Moscow, 2018) p. 368
13. A. Myskin, Common ownership of residential premises: theory of civil law and practice of the Supreme Court of the Russian Federation (Statute, Moscow, 2018) p. 128

14. S. Nikolyukin, Modern Lawyer, 3, 43-54 (2015)

15. T. Kochanova, Housing Law, 8, 63-70 (2018)

16. K. Pryazhennikova, Notary, 2, 22-25 (2020) 